\title{
Tidal variations in bacterial biomass, productivity and oxygen uptake rates in a shallow channel in the Oosterschelde basin, The Netherlands*
}

\author{
H. J. Laanbroek** \& J. C. Verplanke \\ Delta Institute for Hydrobiological Research, Vierstraat 28, 4401 EA Yerseke, The Netherlands
}

\begin{abstract}
Distribution of bacterial biomass, productivity, and oxygen uptake rates were studied in a shallow tidal channel during 3 tidal cycles in spring and late summer. Maxima in concentrations of suspended particles, bacterial biomass and productivity were always observed around the turn of low tide. Numbers of attached bacteria, but not numbers of free-Iiving bacteria, were always significantly correlated with amounts of suspended matter. In spring, the percentages of attached bacteria were correlated with the tide, whereas in late summer the percentages of attached bacteria were more uniformly distributed during the tidal cycle. A significant correlation was always observed between the numbers of attached bacteria and bacterial productivity. The numbers of free-living bacteria and bacterial productivity were only correlated in late summer. In spring, bacterial doubling times were most dependent upon the tide compared to late summer. In comparison to bacterial biomass and productivity, oxygen uptake rates were less regularly distributed during the tidal cycles, probably by the influence of primary production. A mean bacterial carbon conversion coefficient of $40 \%$ was calculated from the data on bacterial productivity and oxygen uptake rates.
\end{abstract}

\section{INTRODUCTION}

Planktonic bacteria in shallow waters may be stimulated by the close vicinity of highly productive sediments. Elevated numbers of bacteria were found during outgoing tides in surface microlayers at the airwater interface of water returning from salt marshes (Harvey et al. 1983). Bacterial growth rates, determined by incorporation of tritiated thymidine into DNA, were relatively high over coral reef flats and seagrass beds (Moriarty \& Pollard 1982, Moriarty et al. 1985). Here, we report a study on the effect of an intertidal mudflats on bacterial numbers and productivity in the overlying water. The study was done in a tidal channel surrounded by extensive intertidal mud. flats. At high tide, the channel is flooded with water from the deeper parts of the basin. At low tide, the channel is filled with water from above the mudflats

In order to measure specifically the bacterial compo-

\footnotetext{
- Delta Institute for Hydrobiological Research Communication No. 335

- Addressee for correspondence; present address: Institute for Ecological Research, Boterhoeksestraat 22,6666 GA Heteren, The Netherlands
}

nent of total pelagic activity, incorporation of tritiated thymidine was applied. Since determination of oxygen consumption rates provide a simple and hence widely used method for measuring heterotrophic activity in aquatic systems (Straskrabova 1979) these measurements were also included in the study. However, the method is not very selective with regard to heterotrophic activity (Williams 1981).

\section{METHODS}

Description of the area. The Oosterschelde basin in the south-western part of the Netherlands is a former estuary still in open connection with the North Sea. However, the discharge of freshwater from the rivers Rhine and Meuse is regulated by sluices. The maximum total input of freshwater amounts to $50 \mathrm{~m}^{3} \mathrm{~s}^{-1}$, whereas the mean volume of the basin is $3050 \times 10^{6} \mathrm{~m}^{3}$. As a consequence the basin is well mixed with a salinity of ca $27 \%$. The mean depth of the basin is $8 \mathrm{~m}$ and the total surface area amounts to $380 \mathrm{~km}^{2}$, of which $44 \%$ is intertidal.

The Sampling Station was chosen in the Mossel- 
kreek, a tidal channel in the most eastern, shallow part of the basin. It is surrounded by extensive mudflats. The tidal amplitude at the sampling station was $4 \mathrm{~m}$ and the minimum depth was $1.5 \mathrm{~m}$. Maximum current velocities, up to $50 \mathrm{~cm} \mathrm{~s} \mathrm{~s}^{-1}$, were recorded around the turn of low tide.

Sample collection. Samples were collected from half-depth during 3 tidal cycles in June and August 1984. Incubations were done on board at in situ temperatures. Samples for analyses were filtered directly on board and stored at $4{ }^{\circ} \mathrm{C}$.

Biomass estimates. Samples for enumeration of freeliving and attached bacteria were preserved by addition of $2 \%$ formaldehyde (final concentration). Direct counts of free-living and attached bacteria and simultaneous determinations of mean cell volumes were performed on black-stained $0.2 \mu \mathrm{m}$ polycarbonate filters using the fluorescent dye acridine orange (Hobbie et al. 1977). Bacterial biomass was obtained from bacterial number and mean cell volume by applying a

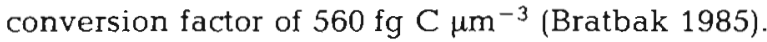

Bacterial production rates. Bacterial production rates were determined with (methyl- ${ }^{3} \mathrm{H}$ ) thymidine incorporation into cold TCA-insoluble material according to the method of Fuhrman \& Azam $(1980,1982)$. Samples of $5 \mathrm{ml}$ containing $5 \mathrm{nM}$ (methyl- ${ }^{3} \mathrm{H}$ ) thymidine $(40 \mathrm{Ci}$ mmole ${ }^{-1}$, Amersham, U.K.) were incubated in $30 \mathrm{ml}$ screw-cap bottles in the dark at in situ temperature for $3 \mathrm{~h}$. Blanks were prepared by addition of $2 \%$ formaldehyde (final concentration). The rate of thymidine incorporation into DNA was converted to bacterial production rates by assuming that $2.1 \times 10^{18}$ cells were produced per mole thymidine incorporated (Fuhrman \& Azam 1982). Cell production was converted to carbon production by applying a conversion

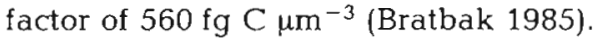

Oxygen consumption rates. As an index of overall heterotrophic activity, oxygen consumption rates were determined. Ten oxygen bottles were filled with water; 5 bottles were immediately fixed and 5 bottles were incubated in the dark at in situ temperature for $24 \mathrm{~h}$ and then fixed. Oxygen concentrations were determined by Winkler titration according to Bryan et al. (1976).

\section{RESULTS AND DISCUSSION}

\section{Bacterial biomass}

The first experiments were done in June 1984 in 2 periods of $15 \mathrm{~h}$. Each experiment included a complete tidal cycle. The first experiment started at sunrise at low tide and lasted until sunset at low tide. The second experiment started $22 \mathrm{~h}$ later at low tide in the evening and lasted until low tide the following morning. The third and last experiment was done in August 1984 and also included a complete tidal cycle. This last experiment started at sunrise at high tide and lasted until sunset at high tide. During the first experiment, water temperature increased steadily from $15^{\circ} \mathrm{C}$ in the morning to $21^{\circ} \mathrm{C}$ in the evening, whereas during the second experiment water temperature decreased again from $20^{\circ} \mathrm{C}$ to $16^{\circ} \mathrm{C}$. During the third experiment, water temperature was fairly constant and fluctuated between 20 and $21^{\circ} \mathrm{C}$.

Due to the high current velocities around low tide (up to $50 \mathrm{~cm} \mathrm{~s}^{-1}$ ), large amounts of particles, mainly mineral, were resuspended from the intertidal mudflats. At this time particle concentrations up to $150 \mathrm{mg}$ $1^{-1}$ were recorded. Around the turn of high tide, on the other hand, particle concentrations were only $10 \mathrm{mg}$ $1^{-1}$. Amounts of dissolved organic carbon were independent of the tide. Analogous to the maxima in particle loading, maxima in bacterial numbers were also recorded around low tide (Fig. 1a \& 2a). Total numbers

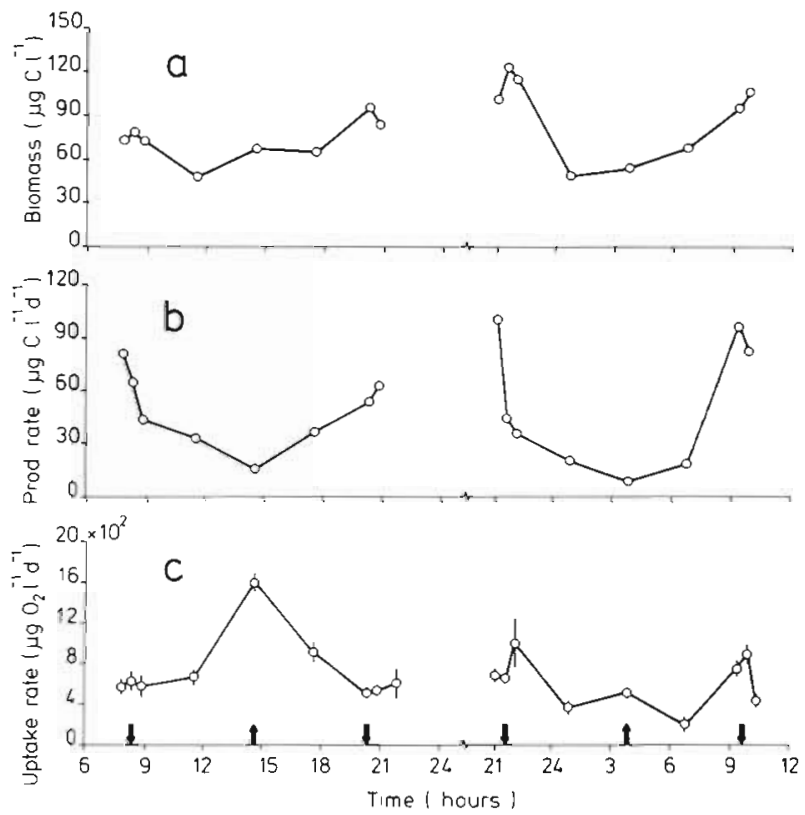

Fig. 1. Distribution of (a) bacterial biomass, (b) bacterial productivity, (c) oxygen uptake rates in a tidal channel of the Oosterschelde basin during 2 tidal cycles in Jun 1984. $\downarrow$ Low tide; $\uparrow$ high tide

of bacteria were indeed significantly correlated with the concentrations of suspended particles (Table 1). The numbers of attached bacteria were also significantly correlated with the concentrations of suspended particles. However, the numbers of free-living bacteria were not always significantly correlated with the concentrations of suspended particles. In the Humber estuary, significant correlations between numbers of attached bacteria and concentrations of suspended 


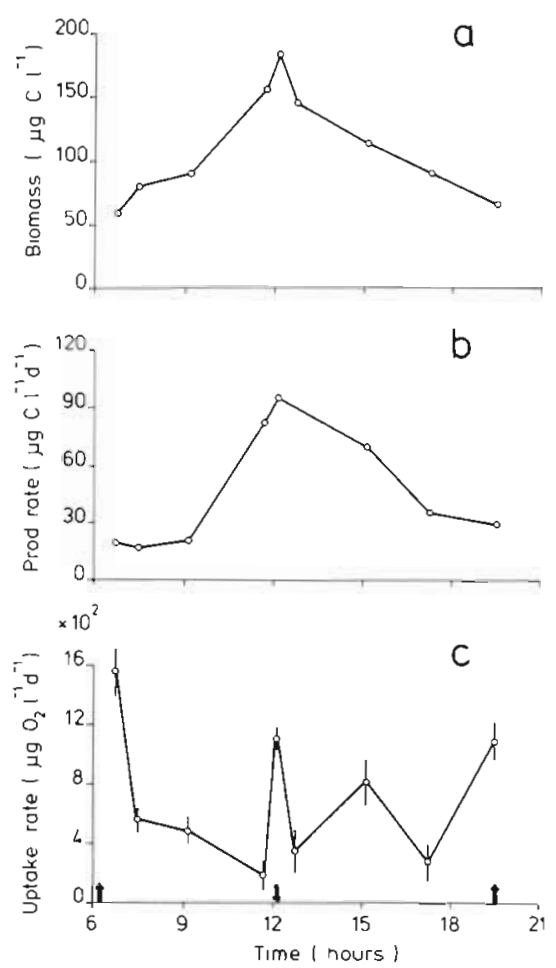

Fig. 2. Distribution of (a) bacterial biomass, (b) bacterial productivity. (c) oxygen uptake rates in a tidal channel of the Oosterschelde basin during a tidal cycle in Aug 1984. $\downarrow$ Low tide; $\uparrow$ high tide

Table 1. Correlation coefficients of the relation between bacterial numbers and concentration of suspended particles observed in a tidal channel during 3 different tidal cycles

\begin{tabular}{|c|c|c|c|}
\hline \multirow[t]{2}{*}{ Log no. of bacteria } & \multicolumn{3}{|c|}{$\begin{array}{l}\text { Log conc. of suspended } \\
\text { particles }\end{array}$} \\
\hline & $\begin{array}{c}26 \text { Jun } \\
1984\end{array}$ & $\begin{array}{c}27 / 28 \text { Jun } \\
1984\end{array}$ & $\begin{array}{c}29 \text { Aug } \\
1984\end{array}$ \\
\hline Total & $0.816^{*}$ & $0.901 \cdots$ & $0.777 \cdot \cdot$ \\
\hline Free-living & NS & $0.874^{\cdots}$ & $0.750^{\circ}$ \\
\hline Attached & $0.925^{\cdots}$ & $0.848^{\cdots}$ & $0.754^{\cdots}$ \\
\hline \multicolumn{4}{|l|}{ NS Not significant } \\
\hline
\end{tabular}

particles were also found, whereas the numbers of free-living bacteria were independent of particle concentration (Goulder 1976, Bent \& Goulder 1981). The same was observed in some coastal zones (Cammen \& Walker 1982, Fukami et al. 1983).

During the first experiments in June, relatively low percentages of attached bacteria were determined around high tide (Fig. 3). Low percentages of attached bacteria are a common phenomenon in the deeper parts of the Oosterschelde basin in spring (Laanbroek \& Verplanke unpubl.). During the August experiment,

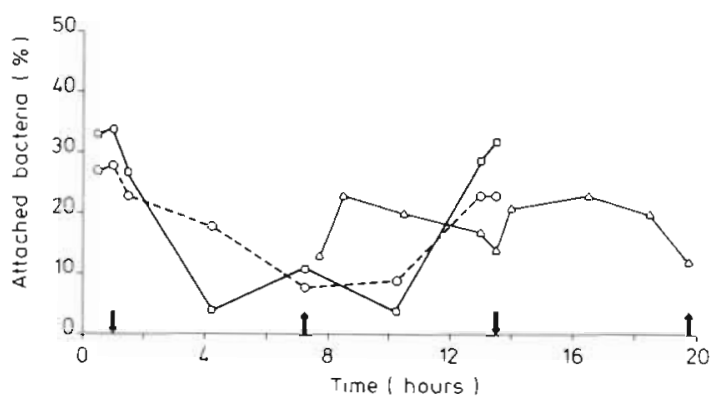

Fig. 3. Distribution of percentages of attached bacteria in a tidal channel of the Oosterschelde basin during 2 tidal cycles in Jun $1984(\square, 0)$ and 1 tidal cycle in Aug $1984(\Delta) . \downarrow$ Low tide; $\uparrow$ high tide

however, the percentages of attached bacteria were more uniformly distributed in relation to the tide, but with distinct minima at tide turns. The observed difference in distribution of attached bacteria between the experiments in June and August could not be explained from physical or chemical environmental conditions. That in the deeper parts of the basin may be caused by a difference in bacterial preference for suspended particles in spring and late summer.

\section{Bacterial productivity}

Simultaneously with the measurements of bacterial biomasses, bacterial productivities were determined by incorporation of (methyl- ${ }^{3} \mathrm{H}$ ) thymidine. Bacterial productivity determined during the experiments agreed well with production rates found in other coastal zones (see Ducklow 1983). Maxima in productivity were always observed around low tide (Fig. 1b, 2b). Tide-dependent heterotrophic activity has also been observed in a salt marsh estuary (Hanson \& Wiebe 1977). Since maxima in total bacterial biomass occurred also around these points of tide, bacterial productivity and biomass seemed to be correlated. However, a significant correlation between bacterial productivities and total numbers of bacteria was not always observed (Table 2). In contrast, bacterial productivities were always significantly correlated with numbers of attached bacteria.

Although the percentages of attached bacteria might be low, they may incorporate comparatively large amounts of substrates (Bell \& Albright 1981, Kirchman \& Mitchell 1982). Numbers of free-living bacteria were significantly correlated with bacterial productivities only during the August experiment. A shift in activity between free-living and attached bacteria depending upon the particle-loading or upon the season has been observed before in coastal zones (Bell \& Albright 1982, Cammen \& Walker 1982). Bacterial doubling times 
Table 2. Correlation coefficients of the relation between bacterial numbers and bacterial productivities observed in a tidal channel during 3 different tidal cycles

\begin{tabular}{|lccc|}
\hline Log no. of bacteria & \multicolumn{3}{c|}{ Log bacterial productivity } \\
& 26 Jun & $27 / 28$ Jun & 29 Aug \\
& 1984 & 1984 & 1984 \\
\hline Total & NS & $0.754^{*}$ & $0.878 \cdots$ \\
Free-living & NS & NS & $0.896 \cdots$ \\
Attached & $0.840^{\cdots}$ & $0.789 \cdots$ & $0.652^{*}$ \\
NS Not significant & & & \\
$\cdot \mathrm{p} \leqslant 0.05 \quad \cdots p \leqslant 0.01$ & $\cdots p \leqslant 0.005$ & \\
\hline
\end{tabular}

were calculated from bacterial biomasses and corresponding productivities (Fig. 4). It should be kept in mind that the calculated doubling times are minimum values, since the actual bacterial productivities may have been underestimated due to non-equilibrium of

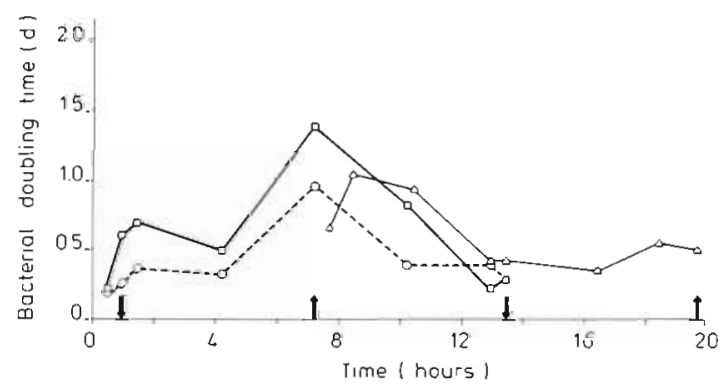

Fig. 4. Distribution of bacterial doubling times in a tidal channel of the Oosterschelde basin during 2 tidal cycles in Jun $1984(\square, 0)$ and 1 tidal cycle in Aug $1984(\triangle)$. $\downarrow$ Low tide; $\uparrow$ high tide

the (methyl $-{ }^{3} \mathrm{H}$ ) thymidine used (Moriarty \& Pollard 1981, 1982, Riemann \& Søndergaard 1984). However, a possible underestimation by non-equilibrium of the nucleotide may be even more severe around low tide when the water in the channel is loaded with particles resuspended from the intertidal mudflats. Compared to the distribution of bacterial doubling times during the tidal cycles in June, the distribution of bacterial doubling times in August was apparently more dependent on diurnal changes than on tidal changes. Hence, the effect of intertidal mudflats on bacterial productivity in the water column is more pronounced in spring than in late summer

\section{Oxygen consumption rates}

Since determinations of oxygen uptake rates provide a simple and hence widely used method for measuring heterotrophic activities in aquatic environments (Stras- krabova 1979), such measurements were included in the experiments. Unlike bacterial biomasses and productivities, oxygen uptake rates were less regularly distributed during the tidal cycles (Fig. 1c, 2c). Bacterial productivities and oxygen consumption rates were never significantly correlated. The absence of correlation between bacterial productivities and oxygen consumption rates can partly be explained by the effect of primary production and partly by the oxygen-consuming activity during incubation in the dark by the algae themselves. During the first experiment in June, primary production was high $\left(80 \mathrm{mg} \mathrm{C} \mathrm{m}^{-2} \mathrm{~h}^{-1}, \mathrm{P}\right.$. R. M. de Visscher pers. comm.) in the middle of the day, since high tide, with low concentrations of suspended particles, occurred at that time of the day. Consumption of oxygen in samples taken around high tide may have been stimulated by primary production in the previous light period. Such a stimulation, however, was not observed in bacterial productivity (Fig. 1b). Two explanations can be given for the observed disagreement between bacterial productivity and oxygen uptake rates. (1) The bacteria in situ were utilizing and oxidizing primary products, but this was not coupled to growth. However, this is very unlikely. (2) Incubation of samples loaded with primary products for longer times in the dark caused high oxygen consumption rates not encountered in situ either by the algae or by the bacteria. Algal respiration in the dark can be high depending upon the previous light period (Stone \& Ganf 1981, Verity 1982). Hence, great care must be taken to extrapolate oxygen consumption rates determined by incubations in the dark to in situ activities in the light. When samples were taken in the dark, as happened in the second June experiment, overestimation of in situ oxygen consumption rates by dark incubations may be less severe. During the experiment in August, primary production was low $\left(25 \mathrm{mg} \mathrm{C} \mathrm{m}^{-2}\right.$ $\mathrm{h}^{-1}, \mathrm{P} . \mathrm{R} . \mathrm{M}$. de Visscher pers. comm.) in the middle of the day, since low tide, with large amounts of suspended matter, occurred at that time of the day. The small maximum in oxygen uptake rate observed during that experiment (Fig. 2c) may have been caused by a short period of high primary production allowed by a rapid sedimentation of suspended particles just at the turn of tide when the current velocity was zero.

Oxygen consumption rates can be converted to carbon mineralization rates by applying a carbon to oxygen ratio of 0.29 (Sepers 1979). From these calculated carbon mineralization rates and the bacterial carbon production rates, a bacterial carbon conversion coefficient can be determined. Assuming that oxygen consumption rates determined by incubation in the dark were similar to in situ rates in the dark and assuming that all the oxygen was used by the bacteria, a mean bacterial carbon conversion coefficient of $20 \%$ was 
determined. However, according to size fractionation experiments, approximately $50 \%$ of total oxygen consumption rates could be attributed to bacterial activity in the Oosterschelde basin in spring (Laanbroek \& Verplanke in press). Hence, the mean bacterial carbon conversion coefficient will be $40 \%$, which is in between the value recorded by Newell et al. (1981) for bacterial utilization of algal cell debris and the value determined by Jensen (1983) for bacterial growth on algal exudates. The calculated value of $40 \%$ represents a lower limit, since actual bacterial productivity may have been underestimated by a possible nonequilibrium of the specific activity of (methyl- ${ }^{3} \mathrm{H}$ ) thymidine as mentioned above.

Acknowledgements. This research was supported by the Delta Service of the Dutch Ministry of Public Works. We are grateful to the crew of the M. S. 'Jan Verwey' for bringing us safely to the sampling station and for their assistance during sampling. In addition we wish to acknowledge Mr P. R. M. de Visscher for making unpublished primary production data available to us, Mr A. A. Bolsius for drawing the figures and Mrs $M$. van Leerdam for typing the manuscript.

\section{LITERATURE CITED}

Bell, C. R., Albright, L. J. (1981). Attached and free-floating bacteria in the Fraser River estuary, British Columbia, Canada. Mar. Ecol. Prog. Ser. 6: 317-327

Bell, C. R., Albright, L. J. (1982). Attached and free-floating bacteria in a diverse selection of water bodies. Appl. environ. Microbiol. 43: 1227-1237

Bent, E. J., Goulder, R. (1981). Planktonic bacteria in the Humber estuary; seasonal variation in population density and heterotrophic activity. Mar. Biol. 62: 35-45

Bratbak, G. (1985). Bacterial biovolume and biomass estimations. Appl. environ. Microbiol. 49: 1488-1493

Bryan, J. R., Riley, J. P., Williams, P. J. LeB. (1976). A Winkler procedure for making precise measurements of oxygen concentration for productivity and related studies. J. exp. mar. Biol. Ecol. 21: 191-197

Cammen, L. M., Walker, J. A. (1982). Distribution and activity of attached and free-living suspended bacteria in the Bay of Fundy. Can. J. Fish. Aquat. Sci. 39: 1655-1663

Ducklow, H. W. (1983). Production and fate of bacteria in the ocean. Bioscience 33: 494-501

Fuhrman, J. A., Azam, F. (1980). Bacterioplankton secondary production estimates for coastal waters of British Columbia, Antarctica and Californía. Appl, environ. Microbiol. 39: 1085-1095

Fuhrman, J. A., Azam, F. (1982). Thymidine incorporation as a measure of bacterioplankton production in marine surface waters: evaluation and field results. Mar. Biol. 66: 109-120

Fukami, K., Simidu, U., Faga, N. (1983). Distribution of heterotrophic bacteria in relation to the concentration of particulate organic matter in seawater. Can. J. Microbiol. 29: $570-575$

Goulder, R. (1976). Relationships between suspended solids and standing crops and activities of bacteria in an estuary during a neap-spring-neap tidal cycle. Oecologia (Berl.) $24: 83-90$

Hanson, R. B., Wiebe, W. J. (1977). Heterotrophic activity associated with particulate size fractions in a Spartina alterniflora salt-marsh estuary, Sapelo Island, Georgia, USA, and the continental shelf waters. Mar. Biol. 42: $321-330$

Harvey, R. W., Lion, L. W., Young, L. Y. (1983). Transport and distribution of bacteria and diatoms in the aqueous surface microlayer of a salt marsh. Estuar. coast. Shelf Sci. 16(5): 543-547

Hobbie, J. E., Daley, R. J., Jasper, S. (1977). Use of nuclepore filters for counting bacteria by fluorescence microscopy. Appl. environ. Microbiol. 33: 1225-1228

Jensen, L. M. (1983). Phytoplankton release of extracellular organic carbon, molecular weight composition, and bacterial assimilation. Mar. Ecol. Prog. Ser. 11: 39-48

Kirchman, D., Mitchell, R. (1982). Contribution of particlebound bacteria to total microheterotrophic activity in five ponds and two marshes. Appl. environ. Microbiol. 43: 200-209

Laanbroek, H. J., Verplanke, J. C. (in press). The use of size fractionation for determining the bacterial contribution to overall pelagic oxygen consumption rates. In: Prieur, D. (ed.) Proc. 2nd Int. Coll. Mar. Bacteriol., Brest 1984. Ifremer/CNRS.

Moriarty, D. J. W., Pollard, P. C. (1981). DNA synthesis as a measure of bacterial productivity in seagrass sediments. Mar. Ecol. Prog. Ser. 5: 151-156

Moriarty, D. J. W., Pollard, P. C. (1982). Diel variation of bacterial productivity in seagrass (Zostera capricorni) beds measured by the rate of thymidine incorporation into DNA. Mar. Biol. 72: 165-173

Moriarty, D. J. W., Pollard, P. C., Hunt, W. G. (1985). Temporal and spatial variation in bacterial production in the water column over a coral reef. Mar Biol. 85: 285-292

Newell, R. C., Lucas, M. I., Linley, E. A. S. (1981). Rate of degradation of efficiency of conversion of phytoplankton debris by marine microorganisms. Mar. Ecol. Prog. Ser. 6: $123-136$

Riemann, B., Søndergaard, M. (1984). Measurement of diel rates of bacterial secondary production in aquatic environments. Appl. environ. Microbiol. 47: 632-638

Sepers, A. B. J. (1979). De aerobe mineralisatie van aminozuren in natuurlijke aquatische milieus. Thesis, Univ, of Groningen, The Netherlands

Stone, S., Ganf, G. (1981). The influence of previous light history on the respiration of four species of freshwater phytoplankton. Arch. Hydrobiol. 91: 435-462

Straskrabova, V. (1979). Oxygen methods for measuring the activity of water bacteria. Arch. Hydrobiol. Beih. Ergeb. Limnol. 11: 3-10

Verity, P. (1982). Effects of temperature, irradiance and daylength on the marine diatom Leptocylindris danicus Cleve III: Dark respiration. J. exp. mar. Biol. Ecol. 60: 197-207

Williams, P. J. LeB. (1981). Microbial contribution to overall marine plankton metabolisms: direct measurements of respiration. Oceanologica Acta 4: 359-364 